Article

\title{
Exploring the Opportunities and Challenges of European Design Policy to Enable Innovation. The Case of Designscapes Project
}

\author{
Chuan Li *(D) and Pau Rausell Köster *(D) \\ Research Unit for Economics of Culture and Tourism, Applied Economics Department, University of Valencia, \\ Av. Tarongers s/n, 46022 Valencia, Spain \\ * Correspondence: chuan.li@uv.es (C.L.); pau.rausell@uv.es (P.R.K.)
}

Received: 27 May 2020; Accepted: 22 June 2020; Published: 23 June 2020

check for updates

\begin{abstract}
Design policy for innovation and prosperity has been acknowledged and adopted globally. Existing literature on design policy usually adopts a top-down perspective to analyse the components of the design innovation system and ignores the practical needs of practitioners. Our study aims to explore potential opportunities and challenges of design policies for design-enabled innovation from a bottom-up perspective. We firstly discussed the enabling role of design in the context of design as input, output and process of innovation with emphasis on design-enabled innovation conception; then European design policies are reviewed in terms of characteristics, priorities and strategies at EU, national and regional levels. Based on multiple case studies on the SWOT (i.e., Strengths, Weaknesses, Opportunities, and Threats) analysis of 50 European design innovation initiatives, we summarised eight dimensions of SWOT factors-organisation, production, performance, knowledge, environment, market, technology and institution-so as to identify main strengths, weaknesses, opportunities and threats that practitioners are facing, and discussed common and specific factors that might influence the identification of SWOT forces by taking into account country and sector factors. We concluded that European design policy is located at a point of intergenerational transition from awareness raising to capacity building, which calls for more coordinated policies to tackle current opportunities and challenges.
\end{abstract}

Keywords: design; design policy; design-enabled innovation; SWOT analysis; factors; Designscapes project; Europe

\section{Introduction}

Not until very recently has particular attention been paid to design for its potential contribution to growth and prosperity, even though the role of design in production and innovation was acknowledged in the earlier works of economist Freeman [1,2] and a report of the Organisation for Economic Co-operation and Development [3].

Such attention has mostly followed two main trends in recent years. First, mainstream studies on innovation have been expanded from the technological to the cultural sphere [4], and use and functional values are no longer the sole determinant factor of value creation in the development of new products and services, whilst aesthetics, symbols and meaning also add value owing to their 'communication' component [5]. Second, design thinking, as well as design methods and tools, have been extensively developed and diffused in the last decades [6]; now it is acknowledged that design is not only valuable in addressing a wide range of managerial issues but is also a powerful tool that can be applied to problem-solving and product development beyond the creative industries [7]. On a local and regional basis, consequently, there have been policy practices that link design to broader cultural 
policy and a strategic regeneration framework with the aim of driving economic, social and cultural development [8].

Indeed, existing literature has shown the significant contribution of design in disciplines which the design sector had hardly considered before. Some examples include the use of design to shape and develop novel concepts and new products [9-11], to underpin business growth [12], to facilitate social innovation [13,14], and to enhance human happiness and subjective wellbeing [15-17], among others. In other words, design has been shown to have great potential in enabling successful innovation in both the private and public sectors.

In addition to design as driver of innovation and development, in a broader sense the Montréal Design Declaration issued in 2017 put forth an additional argument that design creates value for sustainable solutions, cultural expression, human-centred technology and, most importantly, facilitates change to deliver a better life by introducing intelligence to cities.

Accordingly, more and more people across the world are calling for public design policies that build awareness raising and innovation capacity [18]. One such attempt has been the development, implementation and monitoring of previous European design policies at both the European Union (EU), EU member state and regional levels. These practices have encouraged a series of design policy studies aiming to monitor and evaluate outcomes of design policies across Europe [19-22]. These studies shared common characteristics by focusing on the analysis of actors (e.g., design users, agents and sectors), type of interaction (e.g., design support, promotion, and knowledge transfer), and institution (e.g., design support and policies) in a national innovation system from a top-down perspective. However, it is obvious that the absence of a key bottom-up perspective results in entire neglect of the actual needs of beneficiary designers and innovators at a time when public policy-making is moving towards a more citizen-led approach [23]. In addition, the emerging 'nudges' approach—changing people's choice without compelling them [24] -has been increasingly used in EU policymaking, which also stresses the incorporation of public information, ideas and choices at different stages of policy making [25].

Yet it also deserves note that policymaking is a dynamic and evolving process and European design policies have witnessed a subtle but visible change from the earlier awareness-raising phase to the current capacity-building phase. The former places more emphasis on advocating the involvement of the design sector in business and public services and the latter stands for a possible path-dependency model of design-enabled innovation that builds design capacity across sectors by means of design thinking and co-creation approaches, which is evidenced by the recent initiative 'CO-CREATION-02-2016-User-driven innovation: value creation through design-enabled innovation', and the ongoing H2020 project Designscapes, let alone a new strategic agenda for the EU (2019-2024) that creates a wider arena in which design can play a vital role. Seizing these opportunities, international design organisations such as the Bureau of European Design Organisations (BEDA) and the World Design Organisation (WDO) are shaping new overall frameworks of design policy to tackle regional and global challenges. These developments highlight the importance of learning lessons from existing design policies and their outcomes in terms of design-enabled innovation initiatives as a reference for the next generation of design policies in Europe and beyond.

To overcome the limitation and to answer current needs discussed above, this study attempts to adopt a bottom-up perspective to explore potential opportunities and challenges of design policies leading to design-enabled innovation, based on multiple case studies of 50 design innovation initiatives across Europe. The article is structured as follows: first, we address the relation between design and innovation concentrating on three ways in which design could play an innovation-enabling role for input, output and the process of innovation; this is followed by an extended discussion of design-enabled innovation in the context of design as the process of innovation. Afterwards, we review recent design polices in terms of their characteristics, priorities and strategies at EU, national and regional levels. Subsequently, after a review of the data and methodology employed, findings from 
cross-case analyses are reported, and following further discussion we conclude with study limitations and policy implications arising as a result of this study.

\section{Design as Innovation-Enabler}

Design is a common word, but its precise meaning is quite diffuse and unclear owing to confusion, semantic proliferation, and lack of coherence in the existing literature [26]. Traditionally, design is the intangible work by designers concentrating on materiality to give 'form' [27] which is somewhat related to crafting other professional activities. However, currently more emphasis is placed on a knowledge-oriented perspective that considers design as an independent domain involving specific knowledge that can help to create a desired state of affairs [28] and thus is related to all professions rather than merely professional designers [6]. For example, Simon conceives design as 'courses of action aimed at changing existing situations into preferred ones' [29]; Hatchuel and Weil characterise design as 'the generation of new objects and new knowledge' [30]; Dorst describes design as 'the resolution of paradoxes between discourses in a design situation' [31]. All in all, it is concluded that design is a problem-solving process in order to shape a solution [32,33] and, further, these problems are often ill-defined [34], or rather difficult problems [35]. Consequently, design only delivers 'satisfying' solutions instead of optimal ones [36] and yet generates value for users, organisations and even society [6].

Innovation is widely regarded as 'the multi-stage process whereby organisations transform ideas into new/improved products, services or processes, in order to advance, compete and differentiate themselves successfully in their marketplace' [37]. Social innovation follows the same paradigm (i.e., from novelty to market) with meeting social needs as the primary goal [38]. Generally, innovation is characterised as a dynamic, looped and evolving process $[39,40]$ that involves the three stages of invention, innovation and diffusion [41], which correspond to the complete life cycle of innovation including its generation, implementation and upscaling [42].

It follows that design can enable innovation in two ways: first, design is a creative process [26] that links creativity with innovation as well as shaping ideas towards practical and attractive solutions for users and consumers [43]; second, design provides an 'infra-structuring' mechanism [44,45] to support resource aggregation and network generation in a long-term and open-ended manner [46,47], which facilitates the adoption, transition and scalability of new ideas and knowledge in an open-end innovation system [48]. Therefore, instead of sporadic contributions to innovation, design has the potential to underpin the whole life cycle of innovation.

Nowadays there is an increasing body of literature on the conceptual development of design-intensive innovation streams [49], such as design innovation [50], design for innovation [51], innovation by design [2,52], design-led innovation [53,54], design-driven innovation [55,56], and design-enabled innovation [48], among others. These concepts can be largely categorised into three types according to the enabling role of design:

- Design as an input of innovation, whereby design is regarded as a creative resource when applied to specific design domains like graphic design, engineering design, and industrial design, etc. Professional designers are the depositories of design knowledge and, therefore, the main actors of innovation. Through investment in design resources and professionals, firms can not only improve product form and style but also create a symbol that communicates a quality image and product integrity [57]. Owing to its emphasis on ergonomic and/or aesthetic dimensions, this type of innovation is often seen as incremental and a consequence of radical technological innovation in order to adapt users' expectations and thus, is linked to a firm's differentiation strategy. Concepts like design innovation [50] and design for innovation [51] can be included in this category.

- Design as an output of innovation, where design refers to the generation of meaning. The goal of innovation is to achieve novel and radical changes in socio-cultural models of consumer behaviours and values, rather than to meet their expectations with appealing form and aesthetics; 
accordingly, this should be done through radical, rather than incremental, innovation [58]. In this process it is necessary to shape a 'design discourse' [55] based on networked research processes with different parties including users, firms, designers, products, communication media, cultural centres, schools, artists and so on. Along with technology-driven innovation, design-driven innovation acts through radical changes in meaning in the business field, meaning that design should be integral to the business model, and even to organizational strategy, to sustain competitive advantage [53,59]. Verganti's design-driven innovation [56] and its derivative concept, design-led innovation, [53,54], are examples.

- Design as a process of innovation with design as a key problem-solving process. In this context, the stages of the design process largely coincide with those of innovation maturity [47], so that design-centred activities can be properly integrated into the process of innovation and connected to all the other efforts undertaken to stimulate the inception, development and transition of innovation. From this point, design is a 'social technology' [60] that provides an effective user-centred approach to the empowerment of both professional designers and ordinary people, to adopt a new way of engagement in the process of human-oriented innovation within and beyond the organisation and, consequently, with particular emphasis on design's potential to facilitate social innovation as well as measurement of innovation at system level. An example is design-enabled innovation [48].

Despite the common emphasis on the enabling role of design, these three views present clear differences in terms of enabling mechanisms and innovation features. For the purpose of this study we will concentrate on the third category, i.e., design-enabled innovation.

According to Concilio and Tosoni, design-enabled innovation is 'a non-linear, multi-causal, multilevel and networked process of change aimed at producing new functions, uses and meanings while empowering values derived from a shared view of key issues/challenges enabled by the action of design skills and approaches' [61]. It can be further characterised by four aspects [42], as follows:

- it is a human-centred activity that incorporates users into the research and design phase of each innovation process;

- it makes use of specific operational tools to research, contextualise, model, test and re-design;

- it bridges multi-disciplinary knowledge, including scientific, commercial and humanistic;

- it proposes a holistic approach encompassing aspects such as functionality, ergonomics, usability, accessibility, product safety, sustainability, cost and intangibles.

Different from stressing business and managerial innovation at organisation level, design-enabled innovation is more concerned with sociotechnical transition and system changes [62] empowered by design in a more strategic manner. Therefore, design is more than a practical method and tool and, further, it becomes a social technology [60] that accompanies creative practices involved in the innovation process, i.e., design should be regarded as a systemic approach embedded in the creative and innovation capacity of organisations, communities and ecosystems to facilitate interaction and collaboration between design agents and other actors of change in a long-term and open-ended manner and, thus, enabling the transition of innovation from 'niche' to 'regime' and 'scape' levels [47] (p. 67). In this context, design is not just the business of trained designers, even if they remain the main agents [6]; other change agents such as managers, entrepreneurs, politicians and even citizens also need to adopt a design attitude [63] and 'diffuse design' capability [64] to implement innovation successfully.

Evidence extracted from a number of recent empirical studies about the utilisation of service design, strategic design and design thinking to try new ideas, facilitate continuous innovation initiatives and promote the use of highly scalable solutions in manufacturing [65-67], services [68,69], healthcare [70-72], and public administration sectors [73,74], etc., has provided support for public design and innovation policies throughout the world [18], which, in turn, has stimulated investment in the design sector and design innovation practices. 


\section{Design Policies in Europe}

Just as confused and unclear as the concept of design, design policy does not have a clear scientific definition, in part owing to the quite diverse contexts that it covers, and partially due to different approaches by which it is being developed, particularly in Europe. Some define design policy as a translating process from political vision into programmes and actions to develop national design resources in pursuit of their effective use in a given country [75]. Such definition witnesses a notable limitation because of its sole focus on the design sector itself rather than on broader socioeconomic impacts that other public policies usually emphasise. Instead, we prefer to view design policy as a society-oriented and collective activity for generating solutions to complex problems and challenges. Therefore, a more sophisticated perspective needs developing to link design with other public policy areas, e.g., innovation policy [76].

Indeed, design policy is not a novelty in Europe and some European countries have a long tradition of design polices going back for decades. As early as the 1940s-1950s, for example, British and Danish authorities had established design agencies (e.g., the Council of Industrial Design, the predecessor of the UK Design Council) and developed design policies (e.g., the Danish international design agenda) to support the design sector. According to the Danish Enterprise and Construction Authority, Europe has experienced three generations of design policy [77]: the first one took place during the 1990s and placed emphasis on awareness raising of design for enterprises outside of the design sector; the second was developed during the first decade of the 21st century and paid attention to the dissemination of design knowledge to create better functioning markets for design services; the third and the current generation focuses on design as a tool to spur innovation and meet societal challenges. Innovation-oriented design policy is, clearly, still an emerging phenomenon.

The European Union firstly highlighted design policy in 2009 when the European Commission officially recognised design as a driver of user-centred innovation in an internal working document [78] and later declared design for innovation and growth as one of the EU's growth strategies in its flagship initiative Innovation Union [79], accompanied by a set of design action plans, programmes ${ }^{1}$ and projects ${ }^{2}$ with a view to promoting design-driven innovation. It is worth stressing that design-driven innovation in the European policy context does not correspond to what was defined by Verganti [56] but, instead, it stands for a new innovation paradigm leading towards more demand- and user-driven innovation empowered by design activities [78]. A fashionable measure for policy intervention was to encourage closer collaboration between the design sector and outsiders in business and innovation initiatives through EU-funded programmes and projects. Overall, these measures raised global awareness of design and, in turn, called for continuing policy input and capacity-building to support design-driven innovation at the broader EU member state and regional levels.

Evidently, European design policymaking is a dynamic process rather than a stationary state, and this is mostly manifested in the recent change in terminology, from design-driven innovation to design-enabled innovation, in current policy documents. If we called the first phase (2010-2015) the awareness raising phase of EU design policy, because it placed more emphasis on a call for the exploitation of design professionals and resources involved in business and the public sector, the following phrase (2016-2020) could be labelled the capacity building phase because it seems to turn to the exploration of a potential path-dependency model of design-enabled innovation by leveraging design thinking and co-creation approaches to achieve cross-sectorial transfer of design attitudes and capabilities. This may imply an intention to move design policy up the design policy ladder from 'industry design policy' and 'service design' to 'policy for strategic design' [21].

Decentralisation is an important characteristic of European design policy. In addition to direct expenditures on design at the EU level, large-scale and territorial-wide investment in the design professions, facilities and activities have also been adopted to pursue a wide range of societal aims at national and regional level. For example, up to 2015 over half of EU member states had included design explicitly in their national policies (Appendix A) and five of them had further developed national design action plans $[20,21]$. Further, their policy priorities are quite different: Italian and Portuguese 
policies focus on traditional design, Greek and Spanish policies on industrial design, Slovenian policies on service design, and Danish and British policies on strategic design [19]. Yet there is also uneven development of the design sector and the degree to which design policy is incorporated varies across Europe; in this sense, Demark and Sweden can be considered as design leaders, whilst France and Ireland are design followers and Austria and Estonia are design users [19].

Schuster argues that cultural policies, explicit or implicit, are translated into action through programmes with three primary elements-action tools (e.g., incentives, regulation, information, intellectual property rights (IPR), available resources (e.g., cash, personnel and capital), and institutional arrangement (e.g., government operations, policy surrogate (i.e., external organisation contracted or granted by government), quasi-autonomous non-governmental organisations (QUANGOs) through which policy actors try to achieve intended outcomes and specific targets [80].

Following Schuster's argument, and based on the details of different European design programmes in the existing literature [19-22], we can put forward some concrete ideas about European design policies as follows.

First, design policies at EU level are explicitly featured in umbrella policy documents [19] whilst those at national and regional levels are mostly characterised by implicit policies and shaped by the generic interests of the design and commercial communities in the manifestation of different design programmes and projects.

Second, except for a few of programmes that were operated directly by government bodies and public agencies, such as Enterprises Flanders-a government-funded agency-in SME Wallet, most programmes were established through two main institutional arrangements: one is policy surrogate, which is often based on a consortium built by cross-sectoral and public-private partnership, such as the government-industry-university cooperation involved in Design Silesia [81], and another is the QUANGO that is usually embodied in design centres (e.g., UK Design Council in Design Leadership Programme and the Danish Design Centre in Design Boost), chambers of commerce (e.g., the Chamber of Commerce of Milan in A designer for enterprises) and specialised associations (e.g., Vàlencia Capital del Disseny association in the Bid for World Design Capital 2022 initiative).

Third, information, training, consultation and funding are the four mostly utilised tools. Through direct budgetary expenditures and subsidies on the one hand, many programmes conduct training courses and monitoring workshops concerning design knowledge and a design thinking approach to raise public awareness of the value of design and to enrich the human and financial capital in design-intensive activities. An example is a design training project Design Boost with short intensive intervention courses about specific design challenges; on the other hand, they also supply enterprises with design management consulting to undertake in-house design activities. Design and Craft for the Trentino Region is an example with emphasis on pairing designers and entrepreneurs/craftworkers for new product development.

Fourth, the cultural policymaking process from specific targets to intended outcomes is often accompanied with the diagnosis of reality [80], i.e., detecting and overcoming dysfunctionality with necessary intervention strategies relying on available tools, resources and institutional arrangements [82]. Based on this assumption, therefore, we can summarise four types of design policy in terms of diagnosis, target, outcome and tools, described in Table 1. Briefly, awareness strategy aims to stimulate demand for design by promoting information-sharing, peer learning, and network building, to raise public awareness; provision strategy intends to augment the supply of design through direct public investment, skill-training, and setting, thus, fostering collective capacity to deliver design-enabled innovation; incentive strategy concentrates on the enhancement of the willingness to adopt design, with government subsidies and tax incentives for design-intensive activities; and recognition strategy focuses on the protection of acknowledged rights and benefits resulting from design-enabled innovation by establishing necessary innovation appropriation mechanisms, e.g., IPR support. In Table 1, it is shown that all four strategies could be embedded simultaneously in each single programme, but awareness and provision Strategies are the most highlighted among them. 
Table 1. Examples of European design programmes and four strategies for the diagnosis of the reality.

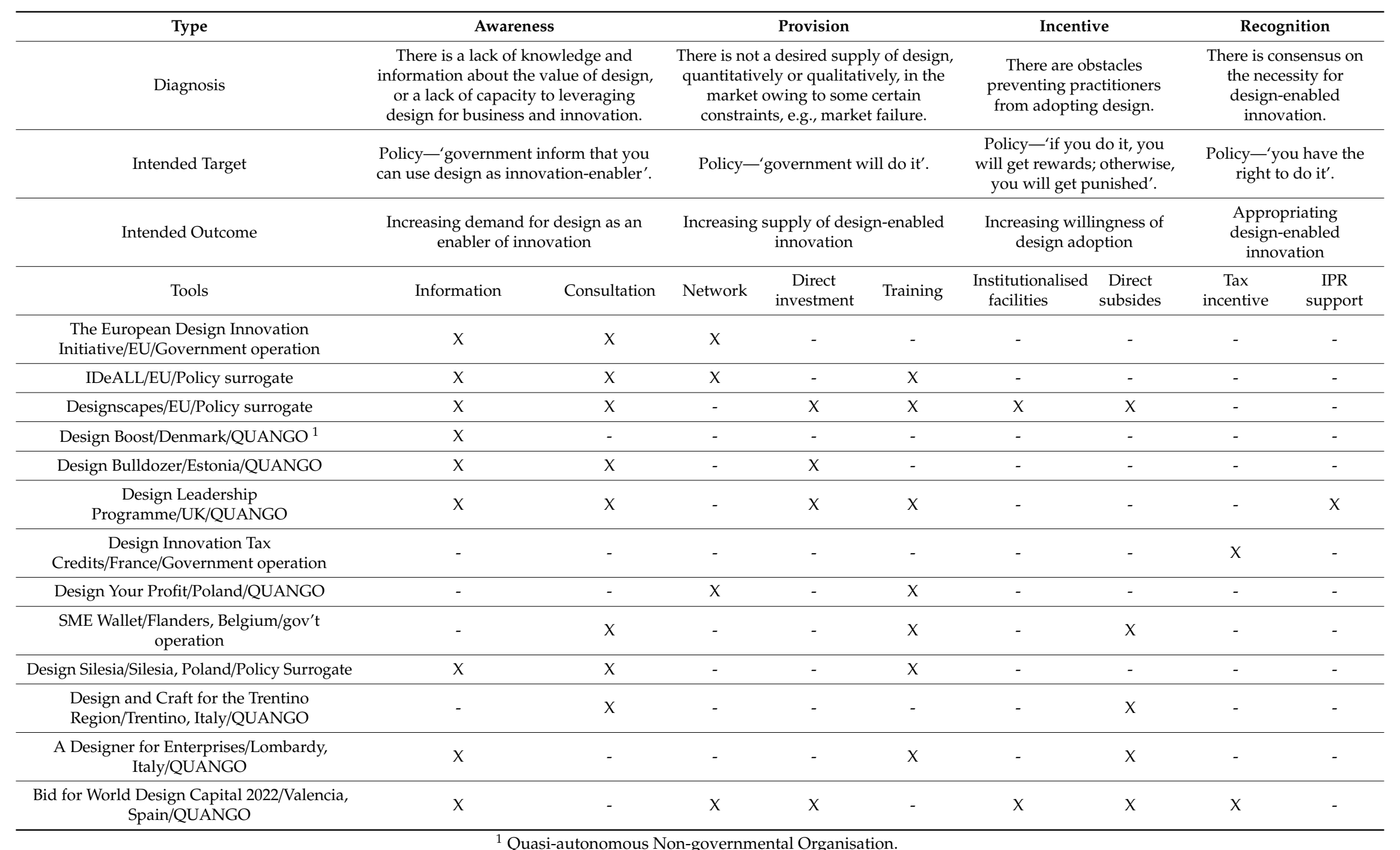

${ }^{1}$ Quasi-autonomous Non-governmental Organisation. 


\section{Materials and Methods}

\subsection{Materials Collection}

Our study relies on materials from a self-assessed SWOT analysis of 50 design-enabled innovation initiatives (codified as P1-50) across Europe. They are extracted from a survey conducted by Designscapes - an EU Horizon2020 project with the overarching aim of building capacity for design-enabled innovation in urban environments. The project issued a three-stage competitive open call for supporting feasibility, prototype and scalability of design-enabled innovation initiatives in European cities. The survey was conducted in the first stage of call for feasibility studies on 13 July and 30 November 2018.

The SWOT analysis was part of the compulsory questionnaire integrated in the application procedure, with most respondents providing long lists of descriptive items about strengths, weaknesses, opportunities and threats to their initiatives in an open-ended manner. Finally, a group of cross-sectorial evaluators from academia, industry and government sectors selected the top 50 proposals-out of 263 applications - according to a set of criteria ranging from co-creation, urban embedding, social inclusiveness, upscaling potentials, and prospective impacts. Considering that the evaluation was based exclusively on the details and quality of articulation, our analysis only focused on the top 50 proposals by quality, integrity and credibility of data.

A SWOT analysis is one of the most respected and prevalent tools/techniques of strategic planning [83] and it assists in the identification of internal factors (strengths and weaknesses) and the external environment (opportunities and threats) as well as the development of suitable strategies for organisations, industries and countries [84,85]. Importantly, these factors play a role dynamically-one's strengths could be the weaknesses of another and opportunities adopted by competitors may become threats; moreover, environmental forces identified as external opportunities or threats to an organisation would constitute components classified as internal strengths or weaknesses within an industry or country [85]. Because the goal of design policy is to foster a favourable environment for design by tackling the weaknesses and capitalising on the strengths [20], findings from the SWOT analysis can provide valuable insights into opportunities and challenges for policies of design-enabled innovation.

\subsection{Materials Processing and Analysis}

We utilised the qualitative data analysis software ATLAS ti. to process the collected textual data. We first read texts and codified a total of 492 quotations, which were classified into 60 factors in terms of the semantic meaning of the documented sentences; then they were further synthesised into 18 clusters based on thematic areas; finally, these clusters were categorised into the four groups of strength, weakness, opportunity and threat. The resulting output is reported in Figure 1, where numbers in parentheses represent the sum of quotations involved in the factor and cluster levels, and the darker shading indicates a higher density of quotations involved in the factor level. 


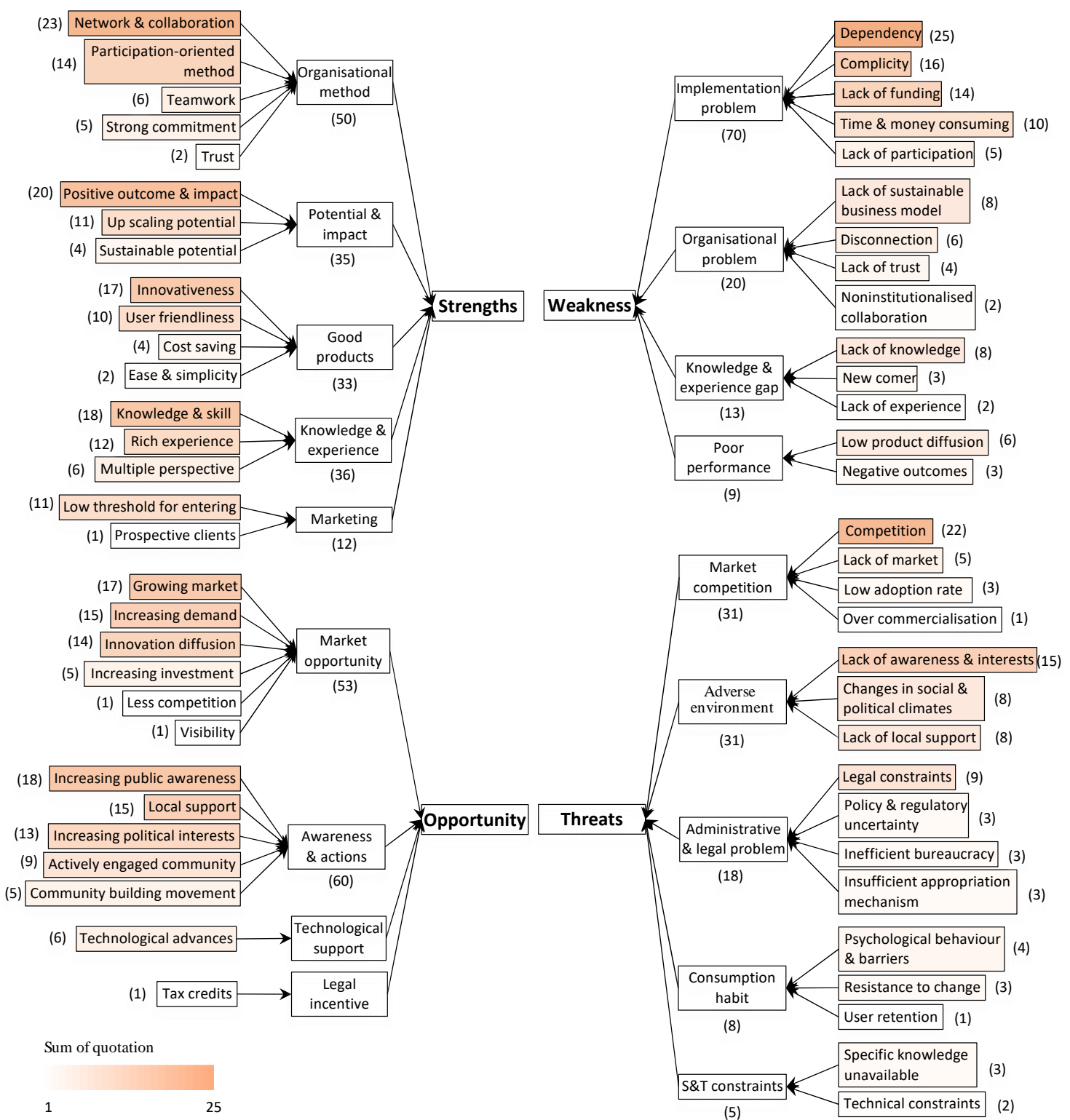

Figure 1. Results of the SWOT analysis on ATLAS ti.

Based on the above, we utilised multiple case studies to analyse and compare the main factors and dimensions that constitute strengths, weaknesses, opportunities and threats that design-enabled innovation initiatives are facing by taking into account country and sector factors, dividing our analysis into three steps. The first step was to identify the overall facets and dimensions of the SWOT factors, prioritising by the agglomeration of clusters and factors identified. The second step was to identify the best documented factors which were, at the same time, the most representative in each dimension. The third step was to summarise a series of common and specific factors that reflected pre-set countries and sectors. We believe that these major common factors are a good representation of the SWOT categories and could play an important role in design policymaking.

It is worth noting that, owing to the nature of qualitative analysis, the number of cases is not a primary consideration in this study, but a greater number of cases usually deliver more robust results in case study methodology [86]. When taking into account country and sector factors, it is particularly important to have a sufficient number of cases in each category of country and sector, dictating that our analysis on common and specific factors had to focus only on Denmark, Italy, Netherlands and UK-the four countries with the most cases that, together, account for three-fifths of all quotations. 
Similarly, of the five sectors considered-academia, business, civil society, people and government-we paid more attention to the first four owing to an insufficient number of cases for the government category in spite of all five sectors being included to ensure the integrity of analysis. For the purpose of this analysis we defined civil society as non-profit and non-governmental organisations, and people as individuals or a collection of persons not affiliated with any organisation.

\section{Results}

\subsection{A Brief Description of Multiple Cases}

We have studied 50 design-enabled innovation initiatives from different countries and sectors across Europe (see Figure 2), and locally concentrated in areas with a strong design tradition. Although they cover 39 cities from 18 countries, with the Netherlands hosting the most cases (11), followed by Italy (8), the UK (6) and Denmark (4), most are concentrated in and around the cities of Amsterdam, Rotterdam, Milan and London. An uneven sectorial distribution is also evident, with nearly half of all cases coming from the business sector (22), followed by people (13), academia (7), civil society (6) and government (2). It is possible to see that projects from the north of Europe are run mostly by business organisations and businesspeople whilst those from the south of Europe are more diverse in terms of the type of applicant.

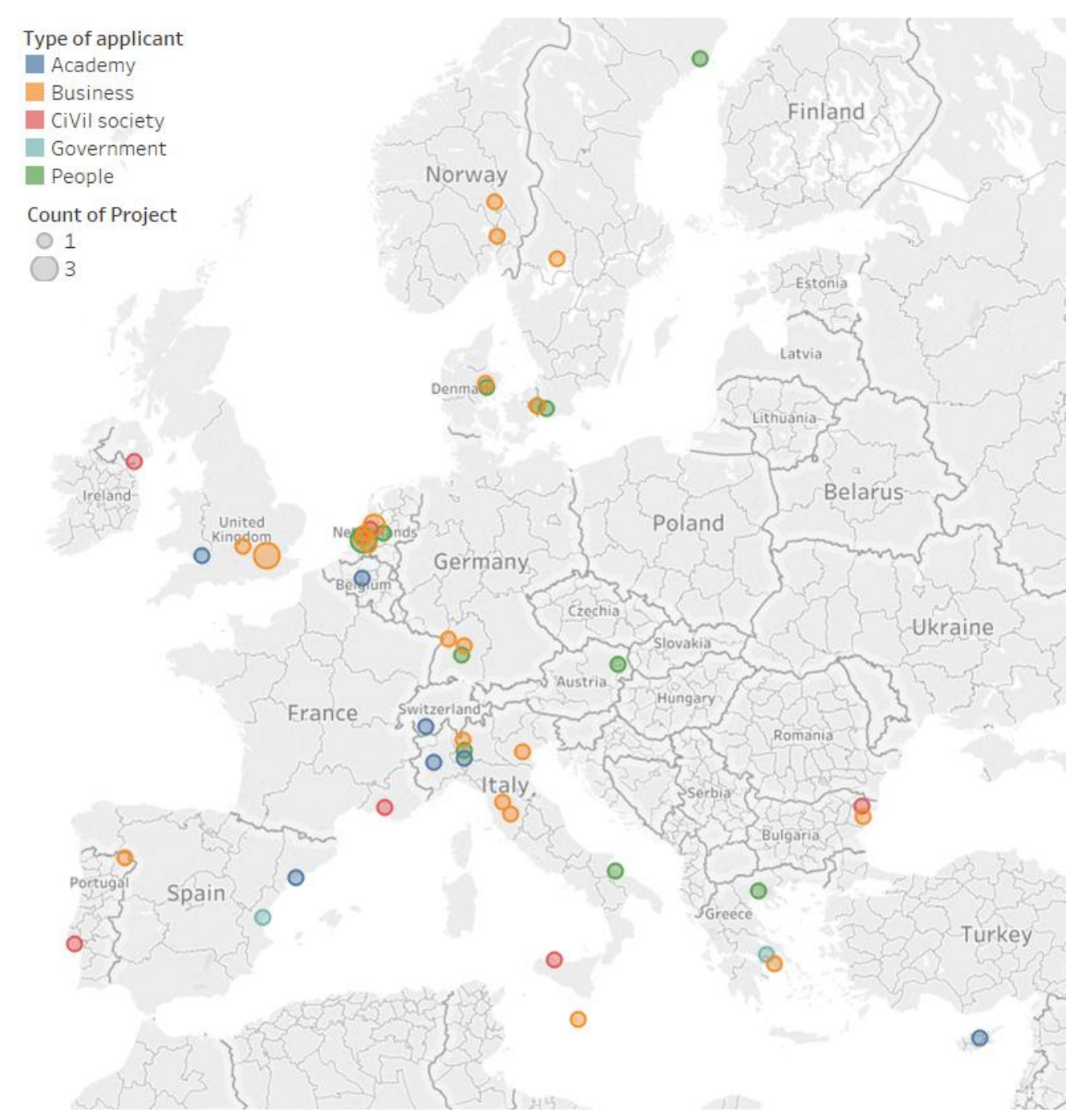

Figure 2. Geographical and sectorial distribution of 50 design-enabled innovation initiatives. 


\subsection{Dimensions of SWOT Factors and Prioritisation}

A summary of factors and clusters from the SWOT analysis of 50 design-enabled innovation initiatives is shown in Figure 1, from which it could be deduced that clusters are, to some extent, two sides of the same coin. In spite of different facets of opportunity and threat, for example, the two clusters 'market opportunity' and 'market competition' could be included in the same market-based dimension, despite having contrasting impacts. Pairing up and aggregating the above clusters can result in a total of eight dimensions of SWOT factors, including performance, organisation, knowledge, production, environment, market, institution and technology. Figure 3 illustrates the components and proportion of dimensions, clearly showing the diversity in terms of the sum of quotations and aggregate impacts.

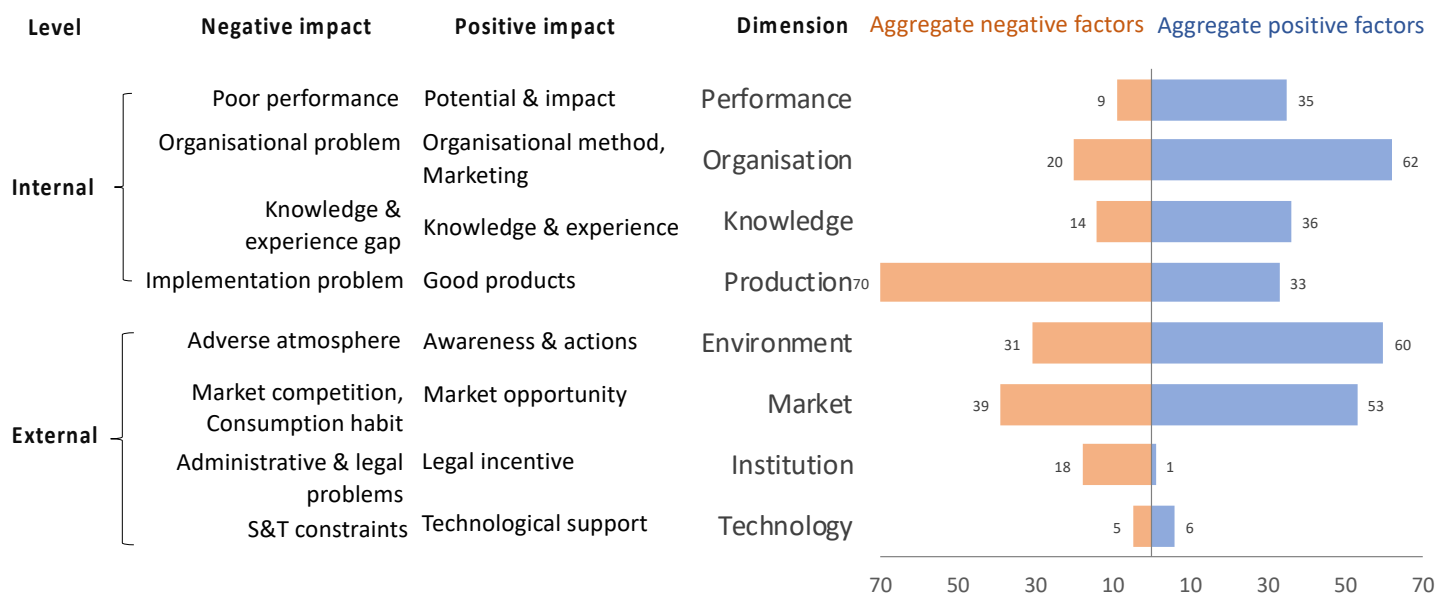

Figure 3. Positive and negative impacts of influential factors at eight dimensions based on the SWOT analysis.

From the sum of quotations, it is clear that more concerns are expressed in the four dimensions of organisation, production, environment and market than in the others, namely performance, knowledge, institution and technology, which could guide the priorities of practitioners. In view of the aggregate impacts, it should be obvious that the five dimensions of performance, organisation, knowledge, environment and market exert a net positive impact, with strengths/opportunities outweighing weaknesses/threats; conversely, production and institution result in a net negative impact by this same standard. Technology stands out as having an equivalent impact on both positive and negative factors, probably reflecting the coexistence of opportunities and threats.

From this, we could assume four types of SWOT forces that encompass the above eight dimensions by level and relative importance, i.e., (1) organisation and production as primary internal forces; (2) environment and market as primary external forces; (3) performance and knowledge as secondary internal forces; and (4) institution and technology as secondary external forces. Internal and external levels are defined by SWOT diagram per se and the relative importance is assessed by the aggregate amount of quotations included in each dimension. In the following sections we explore the above four types of SWOT factors in greater detail.

\subsection{Identifying Major Factors}

In this section we explore the major factors that constitute the main attributes of each dimension and their impact on design-enabled innovation initiatives as a whole, and identify with greater precision the strengths, weaknesses, opportunities and threats faced by design-enabled innovation from the practitioner's perspective. Here, major factors are defined as those with a threshold value of 10 quotations. These major factors and main manifestations of the SWOT analysis are reported in Table 2. 
Table 2. Main manifestations of the SWOT analysis on design-enabled innovation initiatives.

Strengths

- (Organisation) Networking \& collaborating with universities and expert groups (examples include P17, 35, 43, 48, hereinafter), partners (P41, 42, 45), citizens and local communities (P30, 32), firms and industries $(\mathrm{P} 31,44)$, local authorities $(\mathrm{P} 1,6)$, and other change agents like volunteers, NGOs and other stakeholders (P23, 29, 31).

- (Organisation) Adopting participation-oriented method to generate ideas and share knowledge in a co-creation scenario $(\mathrm{P} 7,22,34,43)$, engaging stakeholders in the process of innovation (P16, 20, 40, 48), and dialogue between citizens on a daily basis (P16, 42).

- (Organisation) Low entrance of design innovation because of resource and capability $(\mathrm{P} 12,15,41)$, business model $(\mathrm{P} 31,40)$, and proximity to end-users (P5).

- (Organisation) Innovativeness in developed tools and methods (P11, 19, 26, 32, 39, 43, 50) and utilised technologies (P13, 15, 25, 44).

- (Organisation) Highlighting user-friendliness based on consumer experience $(\mathrm{P} 15,20,38,41,47)$ and participatory engagement (P11, 12, 28, 49).

- (Performance) Exerting positive outcome and impact in relation to addressing societal challenges (P12, 14, $18,19,47)$, socioeconomic value creation $(\mathrm{P} 30,31,39,42)$. culture and citizen-centred urban regeneration (P3, 14, 34), and democracy-building and civic engagement (P22, 30).

- (Knowledge) Wide knowledge and skills ranging from design and co-creation (P2, 4, 32, 42, 49) to scientific methodology (P8, 15, 24, 44), technologies (P24, 26, 48, 49). and management (P40, 42).

- (Knowledge) Rich experience in prior projects with similar topics (P1,2,4,17), design theories and practices (P5, 6, 24, 42), and in project-oriented collaboration (P20, 29, 48).

Weaknesses

- (Production) Success depends on multiple preconditions, e.g., product quality (P18, 20, 50), external partnership (P6, 25, 26, 28, 29), motivation and commitment (P23, 35, 39, 41), supply chain and market (P37, 46, 49), tools and methods (P34, 36), business strategies (P24), fundraising (P34).

- (Production) Too complicated to operate effectively, e.g., products are difficult to be understood by end-users $(\mathrm{P} 1,5)$, direct cooperation with stakeholders required $(\mathrm{P} 3,13,15)$, profound study and assessment needed $(\mathrm{P} 1,8,9)$, complicated technical solutions involved (P15, 28, 30, 35), uncertainty in prototype \& end-products (P19, 43, 45), and conflicts between short-term expectation and long-term impact (P14).

- $\quad$ (Production) Lack of funding for project implementation (P3, 9, 12, 31), investment in infrastructure (P13, 14, 16), and sustainable development (P13, 20, 37).

- (Production) Time and money consuming, particularly in motivating stakeholder participation (P8, 25, 39, $41,45)$.

\section{Opportunities}

- (Environment) Increasing public awareness on environmental protection (P7, 19, 21, 28, 35, 48), urban sustainability $(\mathrm{P} 1,6,14,16,36)$, and emerging economic models (P3, 6, 40) facilitating the engagement of citizens and local community in user-centred innovation.

- (Environment) Increasing political interests in bottom-up decision making (P6, 34, 47), citizen-participation democracy $(\mathrm{P} 15,37,39)$, and the commitment to public goods (P10, 11, 17, 21, 28, 37) encourages citizen-engaged initiatives and innovations for public interests.

- (Environment) Local support for innovative community-engaged model of social innovation (P1, 15, 19, 41) and new business opportunities (P7, 11, 31, 43).

- (Market) Fast growing market for innovative goods \& services greatly decreases production and transaction cost $(\mathrm{P} 19,21,46)$ and easily commercialise innovations (P25, 26, 28, 32, 35, 38).(Market) Increasing demand for healthcare and wellbeing $(\mathrm{P} 1,8,11,27)$, civic engagement $(\mathrm{P} 6,10,13,22,39)$ and sharing and recycling economy $(\mathrm{P9}, 19,21)$ creates more market potential of demand-pull innovation to respond to social needs.

- (Market) Innovation diffusion facilitates followers to adopt new products and services (P9, 14, 23, 37), new technologies $(P 8,35)$, and new business models $(P 13,19,47)$ at regional and local market.

Threats

- (Market) Competing with other enterprises on price (P11, 37, 40, 48, 49), differentiation (P6, 8, 21, 23, 27), and funding and other urban resources (P9, 15, 35).

- (Environment) Lacking awareness of and interest in specific societal problems (P1, 2, 10, 14, 15, 42) and community-engaged approach (P7, 13, 47). 
Overall, these can be summarised into four aspects. First, most major factors relate to the four dimensions of organisation, production, environment and market, at the primary level of the SWOT analysis. Second, only three factors appear in the performance and knowledge dimensions, highlighting the importance of knowledge, skills and experience, as well as outcome and impact, on the secondary internal level. Third, there are no entries in the secondary external level, which could imply the lack of a shared understanding of opportunities and threats in the institutional and technological fields. Last but not least, most major factors have a positive effect, except production-related factors, which are, to a large degree, adverse. We think these characteristics are generally consistent with the overall assessment of SWOT data discussed earlier.

\subsection{Common and Specific Factors among Countries}

It is undeniable that some exogenous factors, such as country and sector, might influence the identification of SWOT forces by organisation and individual owing to their particular context, specific limitations, and the different resources they can access. These difference between common factors (i.e., shared by all countries and sectors) and specific factors (i.e., evidenced by only one or two countries and sectors) are explored in greater detail in the next two sections.

First turning to our analysis by country, Table 3 lists all common and specific factors identified among the four selected countries of Denmark, Italy, the Netherlands and the UK with major factors in bold. Note that there are no entries for common factors under secondary external factors. It is remarkable that most common factors are also characterised as major factors with positive effects. In particular, all internal factors have a positive effect on the organisation and performance dimensions, the same as in the external market dimensions, except for competition that is regarded more negatively; meanwhile production, knowledge and environmental factors reflect an equal number of positive and adverse effects.

Specific factors are, in turn, largely dominated by adverse effects. There is a good number of country-specific factors that do differ from country to country: Italy and UK pay more attention to internal strengths and weaknesses of initiatives while Denmark and the Netherlands show more interests in external opportunities and threats. Beyond the organisational and production advantages, mostly embodied by the adoption of participation-oriented methods, the Italian cases identify weaknesses in production and performance, particularly due to insufficient funding; British cases mainly emphasise insufficient funding and lack of prior experience as specific weaknesses; Danish cases benefit from local support and investment as well as technological advances, but see a specific threat in poor user retention and changes to the social and political climate; Dutch cases emphasise marketing, institutional and technological opportunities but worry about the potential harm resulting from over-commercialisation, insufficient appropriation mechanisms and the constraints of science and technology.

This can, perhaps, be explained by the differences in policy intervention and actor engagement from the national innovation system perspective [87]. European design policies are often integrated into national innovation policies wherein each country may experience different environments and resources, as well as different levels of engagement under the same innovation ecosystem [22], let alone the remarkable gap between the statements of government in relation to design and the implementation of design policies and initiatives among countries [21]. 
Table 3. Common and specific factors by country (Demark, Italy, the Netherlands and the UK).

\begin{tabular}{|c|c|c|c|c|}
\hline \multirow{5}{*}{ Internal level } & \multicolumn{2}{|c|}{ Primary Force } & \multicolumn{2}{|c|}{ Secondary Force } \\
\hline & \multicolumn{2}{|c|}{ Organisation } & \multicolumn{2}{|c|}{ Performance } \\
\hline & $\begin{array}{c}\text { Common } \\
\text { Network \& } \\
\text { collaboration }{ }^{1} \\
\text { Low threshold for } \\
\text { entering }^{1}\end{array}$ & $\begin{array}{c}\text { Specific } \\
\text { Participation-oriented } \\
\text { method }(I T)^{1} \\
\text { Trust }(N L)\end{array}$ & $\begin{array}{c}\text { Common } \\
\text { Positive outcome } \\
\text { \& impact }{ }^{1} \\
\text { Upscaling potential }\end{array}$ & $\begin{array}{c}\text { Specific } \\
\text { Sustainable potential }(N L) \\
\text { Low product diffusion } \\
\text { (IT } \mathcal{E} D K) \\
\text { Negative outcome } \\
\text { (IT } \& N L)\end{array}$ \\
\hline & \multicolumn{2}{|c|}{ Production } & \multicolumn{2}{|c|}{ Knowledge } \\
\hline & $\begin{array}{l}\text { Common } \\
\text { User friendliness } \\
\text { Innovativeness }^{1} \\
\text { Dependency }^{1} \\
\text { Time \& money } \\
\text { consuming }^{1}\end{array}$ & $\begin{array}{c}\text { Specific } \\
\text { Ease \& simplicity }(I T) \\
\text { Cost saving }(I T) \\
\text { Lack of funding }(I T \mathcal{E} U K)^{1}\end{array}$ & $\begin{array}{c}\text { Common } \\
\text { Knowledge \& } \\
\text { skill }^{1} \\
\text { Lack of knowledge }\end{array}$ & $\begin{array}{c}\text { Specific } \\
\text { Lack of experience (UK) }\end{array}$ \\
\hline \multirow{4}{*}{ External level } & \multicolumn{2}{|c|}{ Environment } & \multicolumn{2}{|r|}{ Institution } \\
\hline & $\begin{array}{c}\text { Common } \\
\text { Increasing public } \\
\text { awareness }{ }^{1} \\
\text { Local support }{ }^{1} \\
\text { Increasing political } \\
\text { interests } \\
{ }^{1} \\
\text { Lack of awareness \& } \\
\text { interests }^{1} \\
\text { Lack of local support }\end{array}$ & $\begin{array}{c}\text { Specific } \\
\text { Community building } \\
\text { movement }(D K) \\
\text { Changes in social \& political } \\
\text { climate (IT \& DK) }\end{array}$ & $\begin{array}{c}\text { Common } \\
/ /\end{array}$ & $\begin{array}{c}\text { Specific } \\
\text { Tax credits (NL) } \\
\text { Inefficient bureaucracy } \\
\text { (IT)Insufficient } \\
\text { appropriation mechanism } \\
\text { (NL) } \\
\text { Policy \& regulatory } \\
\text { uncertainty (UK) } \\
\text { Legal constraints } \\
\text { (IT \& UK) }\end{array}$ \\
\hline & \multicolumn{2}{|r|}{ Market } & \multicolumn{2}{|c|}{ Technology } \\
\hline & $\begin{array}{c}\text { Common } \\
\text { Growing market }{ }^{1} \\
\text { Increasing demand }^{1} \\
\text { Innovation diffusion }^{1} \\
\text { Competition }^{1}\end{array}$ & $\begin{array}{c}\text { Specific } \\
\text { Visibility (NL) } \\
\text { Increasing investment }(D K) \\
\text { User retention (DK) } \\
\text { Lack of market (IT \& UK) } \\
\text { Resistance to change (IT \& NL) } \\
\text { Over-commercialisation }(N L)\end{array}$ & Common & $\begin{array}{c}\text { Specific } \\
\text { Technological advances } \\
(N L \mathcal{E} D K) \\
\text { S\&T constraints }(N L)\end{array}$ \\
\hline
\end{tabular}

\subsection{Common and Specific Factors among Sectors}

Table 4 lists common and specific factors identified among five selected sectors-academia, business, civil society, government and people-with major factors in bold. As with Table 3, there are no secondary external factors recorded, but in contrast, cross-sectoral factors are no longer dominated by positive effects. In other words, except for the overwhelmingly positive effects in the organisation and performance dimensions, the majority of common factors have an adverse impact on production and knowledge dimensions, while the external environment and market dimensions record an equivalent number of positive and adverse impacts. The above findings denote an insufficient design knowledge base as a common weakness across sectors.

Similarly, the majority of sector-specific factors have an adverse influence and no single one is categorised as major. Yet the gap in the environment dimension suggests that all environment-related factors could be cross-sectorial and may influence different sectors simultaneously. Obviously, each sector has experienced certain specific factors at different levels and dimensions. For example, business-run cases are concerned with a wide range of factors from organisation, production and knowledge at internal level, to market and institution at external level. People share a significant number of internal and external factors with the business sector, including production-based strengths (e.g., cost saving), and market-oriented opportunities (e.g., increasing investment) and threats (e.g., resistance to change and low adoption rate); cases from civil society reflect weaknesses and threats derived from lack of experience and inefficient bureaucracy while, in common with government, they also declare a 
specific weakness as newcomers; finally, academia highlights its market advantage resulting from a lower degree of competition.

Table 4. Common and specific factors by sectors (academy, business, civil society, government and people).

\begin{tabular}{|c|c|c|c|c|}
\hline & \multicolumn{2}{|c|}{ Primary Force } & \multicolumn{2}{|c|}{ Secondary Force } \\
\hline \multirow{4}{*}{ Internal level } & \multicolumn{2}{|c|}{ Organisation } & \multicolumn{2}{|c|}{ Performance } \\
\hline & $\begin{array}{l}\text { Common } \\
\text { Network \& collaboration }{ }^{1} \\
\text { Low threshold for entering }{ }^{1}\end{array}$ & $\begin{array}{c}\text { Specific } \\
\text { Trust (Business) } \\
\text { Noninstitutionalised } \\
\text { collaboration (Business) }\end{array}$ & $\begin{array}{c}\text { Common } \\
\text { Positive outcome } \\
\text { \& impact } \\
\text { impaling potential }^{\text {Upscaling }}\end{array}$ & $\begin{array}{c}\text { Specific } \\
\text { Negative outcome (People) }\end{array}$ \\
\hline & \multicolumn{2}{|c|}{ Production } & \multicolumn{2}{|c|}{ Knowledge } \\
\hline & $\begin{array}{c}\text { Common } \\
\text { Innovativeness }{ }^{1,2} \\
\text { Lack of fundingDependency } \\
\text { Complicity }{ }^{1,2}\end{array}$ & $\begin{array}{c}\text { Specific } \\
\text { Ease \& simplicity } \\
\text { (business) } \\
\text { Cost saving } \\
\text { (business \& people) } \\
\text { Lack of participation } \\
\text { (people) }\end{array}$ & $\begin{array}{c}\text { Common } \\
\text { Lack of knowledge } \\
2\end{array}$ & $\begin{array}{c}\text { Specific } \\
\text { Lack of specialist (business) } \\
\text { Lack of experience } \\
\text { (business } \mathcal{E} \text { civil society) } \\
\text { Newcomer } \\
\text { (civil society } \mathcal{E} \text { government) }\end{array}$ \\
\hline \multirow[b]{4}{*}{ External level } & \multicolumn{2}{|c|}{ Environment } & \multicolumn{2}{|c|}{ Institution } \\
\hline & $\begin{array}{c}\text { Common } \\
\text { Increasing public awareness } \\
\text { Actively engaged community } \\
\text { Lack of awareness \& } \\
\text { interests }{ }^{1} \\
\text { Lack of local support }\end{array}$ & Specific & \multicolumn{2}{|r|}{$\begin{array}{c}\text { Specific } \\
\text { Tax credits (business) } \\
\text { Political \& regulatory } \\
\text { uncertainty } \\
\text { (business E people) } \\
\text { Inefficient bureaucracy } \\
\text { (business E civil society) }\end{array}$} \\
\hline & \multicolumn{2}{|c|}{ Market } & \multicolumn{2}{|c|}{ Technology } \\
\hline & $\begin{array}{c}\text { Common } \\
\text { Growing market }{ }^{1,2} \\
\text { Increasing demand }{ }^{1} \\
\text { Innovation diffusion } \\
\text { Competition }{ }^{1,2} \\
\text { Csychological behaviour \& } \\
\text { barrier }^{2}\end{array}$ & $\begin{array}{c}\text { Specific } \\
\text { Less competition } \\
\text { (academy) } \\
\text { Increasing investment } \\
\text { (business E people) } \\
\text { Resistance to change } \\
\text { (business } \mathcal{E} \text { people) } \\
\text { Low adoption rate } \\
\text { (business E people) } \\
\text { Over-commercialisation } \\
\text { (people) }\end{array}$ & Common & $\begin{array}{c}\text { Specific } \\
\text { SET constraints (people) }\end{array}$ \\
\hline
\end{tabular}

${ }^{1}$ Major factors highlighted in bold. ${ }^{2}$ Common factors excluding government cases.

This variability, we think, could be largely attributed to the intrinsic qualities of different sectors-business and people are usually profit-oriented and focused on production and market-related factors; academia is also increasingly focused on the commercialisation of innovation, particularly owing to the Triple Helix model of innovation [88,89] that stresses a key role of universities in academy-industry-government collaboration for industrial innovation. On the other hand, government and civil society, both not-profit types of organisation, are more reliant on external knowledge and experience for public sector innovation and social innovations.

\subsection{Institution and Technology Factors}

Despite secondary external factors varying by country and sector factors, the institution and technology factors as a whole offer considerable opportunities and challenges for design-enabled innovation initiatives.

Overall administrative and legal problems constitute an inescapable threat as many cases suffer from legal constraints on various emerging issues such as blockchain-based platforms and business model innovations under the existing regulatory system $(\mathrm{P} 2,17,19,24,28,31,41)$, uncertainty in future policies and laws concerning education, public spending and Brexit (P5, 6, 44), burdensome and 
inefficient bureaucratic procedures $(\mathrm{P} 3,10,25)$, and insufficient mechanisms for the appropriation of innovation benefits $(\mathrm{P} 8,23,32)$.

Meanwhile, technology is more a double-edged sword: the advancement of technology has greatly expanded the boundary of innovation to improve and scale up existing products and processes (P21, $31,37)$ and enhance interactive user experience $(\mathrm{P} 15,49)$. On the negative side, society does have a higher requirement of knowledge and capacities, which needs to keep pace with the development of technologies to tackle today's challenges. Unfortunately, many innovators are not sufficiently knowledgeable and capable (P2, 3, 19) and technological advancement can become a barrier if innovators cannot upgrade their knowledge and equipment (P18) to reap the benefits from the opportunities resulting from the progress of technology.

\section{Discussion and Conclusions}

The objective of this study is to identify potential opportunities and challenges in design policies for design-enabled innovation. Design policy is essentially a government intervention to stimulate supply of and demand for design to address the failures and capitalise on the strengths of the design innovation ecosystem [20]. We consider that a detailed SWOT analysis of design-enabled innovation initiatives is the most appropriate approach to understand opportunities and challenges.

Based on the study of 50 design-enabled innovation initiatives across Europe, we summarised a series of positive and adverse factors that could be clustered to reflect corresponding strengths, weaknesses, opportunities and threats. Further, we recognised eight dimensions and four types of SWOT forces on the basis of the agglomeration of clusters identified. In essence, design-enabled innovators pay most attention to primary internal and external forces that are mainly embodied in the organisation, production, environment and market dimensions, followed by secondary internal forces focused on the performance and knowledge dimensions and, lastly, to secondary external forces characterised by institution and technology-related factors.

We think such prioritisation of SWOT factors is partially due to the fact that our selected cases belong to 'niche innovations' [62], which concentrate largely on the earlier 'inception' and 'development' stages of maturity [42] that stress the value creation process from production to commercialisation of innovation at the organisation level. That said, knowledge and performance management are more linked to the transition process at regime level, while institution and technology are mostly involved in systemic changes in socio-technical landscapes.

Regarding the diversity of SWOT factors, we analysed in greater detail the major factors that could be most representative for each dimension as a whole, while examining the impact of country and sector factors on the recognition of different SWOT forces. We found that almost all major factors were common and only two-participation-oriented approach and funding shortfall—were country-specific factors, which evidences the possibility of formulating design policy as an overall framework beyond country and sector. Yet country and sector-specific factors affect, in a minor way, certain weaknesses and threats, which may not, in some sense, raise general concerns from the whole country or sector, but are key to the success or failure of innovation at the project level. A good example is tax credits, reported in case P26 and with the aim of capitalising product innovation for the Dutch cycling industry, which might be unavailable to those who focus on other areas, rather than the circular economy in the Netherlands.

Clearly, design innovation awareness and capabilities will increase over time as a result of investments in design and participation in supporting policies [90]. From this point, major, common and specific factors can be a reflection of the width, depth and density with which existing design policy outcomes are assessed. By combining earlier discussion about European design policies and their available strategies, therefore, we can further draw some conclusive reflections as follows.

First of all, European society has witnessed an overall growth in the demand for design as well as the awareness of design-enabled innovation. On the one hand, organisation and performance that are widely confirmed as main strengths of design-enabled innovation show that design principles, 
methods and effects have permeated society to a greater extent, and with the generic implementation of design management and consultation in diverse programmes and projects, particularly in Italy where the participation-oriented method is more valued than anywhere else; on the other hand, a major opportunity originating from extending markets, increasing needs and innovation diffusion also implies the expansion of social demands for innovative goods and services empowered by design. Additionally, despite the threat reported of the shortage of awareness and interests in many cases, a broad range of parallel opportunities driven by a rapid increase in public awareness, political interest and local support has been observed, with design-enabled innovation being increasingly perceived as an important means in the resolution of different global and urban problems, which also means that there is still a long way to go for a global consensus on this particular matter.

Secondly, design-enabled innovation capacity remains weak. This is mainly embodied in the significant weakness arising from co-creation, process and cost problems involved in the process of innovation and production (i.e., the production dimension), which reveals insufficient mobilisation, integration and managerial capability to leverage design for the implementation of innovation, and further amplifies the gap between know-what and know-how knowledge in society. Besides, fierce competition is posing an increasing threat relating to product, price, and resources from counterparts without design engagement, which calls for innovation capacity building via the explicit inclusion of competitive enhancements in design policies.

In some sense, this could be partially attributed to inadequate supply of design, particularly manifested in two aspects. First, both strengths and weaknesses regarding design knowledge and skills suggest that some policy tools, such as training, have played a positive role but more efforts should be invested in maximising intended outcomes, whilst knowledge shortfall as a common weakness acknowledged by all sectors reflects the reality that policies and measures are usually formulated to address national and regional demands at horizontal level without consideration for sectorial needs at horizontal level. Secondly, funding as one of the most widely adopted policy tools is nonetheless deemed a major weakness by Italian and British innovators for the implementation and upscaling of projects, which strongly suggests a gap between policy target and outcome in these countries.

Lastly, institutional and technological environment could be the key to incentive and recognition strategies. Supportive tools, like tax incentive and IPR support, are used sporadically and have a limited impact on specific countries or sectors, and the most significant challenge is to proactively create a favourable institutional atmosphere through the improvement of public administration efficiency, decreasing political and regulatory uncertainty, strengthening innovation appropriation mechanisms, and updating the legal framework. Efforts should also be made to encourage technological transfer activities and to prevent the technological exclusion of people.

\section{Limitation and Implication}

This study has three main limitations due to the data limits. First, there are insufficient cases to support a more comprehensive analysis that involves more countries, beyond Denmark, Italy, the Netherlands and the UK. Second, all studied cases are design-enabled innovation initiatives at feasibility study stage but those at prototyping and scalability stages probably face different SWOT factors. Third, a joint impact of country and sector on SWOT factors is not considered although we have noted a possible correlation between country and sector distributions, which deserves further study in future.

Even so, this exploratory study can contribute to the current debate on the topic of design policy and bring constructive implications for Europe in the midst of the intergenerational transition of design policy.

First, considering the major opportunities and challenges shared widely among countries and sectors, it is feasible to imagine a general framework of design policies that addresses the rising global demands for design-enabled innovation. 
Second, to tackle the failures of specific country and sector factors, design policy should be integrated not only in national innovation systems but also sectoral innovation systems, which calls for vertical policy integration to answer countries' needs as well as horizontal policy integration to respond to sectoral demands.

Third, recognising actual transition of priority from awareness raising to capability building in European design policies, flexible measures should be considered to prioritise the strengthening of design innovation capabilities on the one hand and, on the other, to consolidate public awareness and interest, in line with local and sectoral circumstances, and with a tactical emphasis on the discourse of design-enabled innovation as a powerful problem-solving approach rather than simply reiterating the importance of design.

Fourth, facing the challenges and seizing the opportunities resulting from technology advances in the digital era, new design policies should coordinate with technology/digital policies to enhance technology inclusive education and foster digital innovation capacity in the design sector.

Last, but not least, necessary institutional reforms to provide an efficient, stable and innovation-friendly institutional environment should not be ignored.

Author Contributions: Conceptualization: C.L., P.R.K.; Methodology: C.L.; Investigation: C.L.; Writing-Original Draft Preparation: C.L.; Writing-Review \& Editing: C.L., P.R.K.; Supervision: P.R.K.; funding acquisition: P.R.K. All authors have read and agree to the published version of the manuscript.

Funding: This research was funded by the European Union's Horizon 2020 research and innovation programme, grant number 763784 .

Acknowledgments: We thank Grazia Concilio, Ilaria Tosoni, Talita Medina Amaral for sincere suggestion and discussion on the topic, as well as the support of the Designscapes consortium for materials collection.

Conflicts of Interest: The authors declare no conflict of interest. The funders had no role in the design of the study; in the collection, analyses, or interpretation of data; in the writing of the manuscript, or in the decision to publish the results.

\section{Appendix A}

1. An example of EU-initiated program is Design for Europe, a web-based European design innovation platform to support peer-learning, networking and partnerships with the aim of boosting the adoption of design in innovation policies and support creation of capacity and competences to deliver these policies.

2. Examples of EU-funded design projects are IDeALL, EuroDesign, DeEP, SEE Platform, EHDM, REDI, Design4Innovation and DESIGNSCAPES, among other, which focus on the development of design and innovation theories and practices across Europe under a wide range of topics from value measurement, capacity building, design management and strategies, to policy design, etc.

3. According to Design Policy Monitor (2012, 2014, 2015), 15 out of 28 EU member states including design in their national design policies are Belgium, the Czech Republic, Denmark, Estonia, Finland, France, Greece, Ireland, Italy, Latvia, Poland, Slovakia, Slovenia, Spain, Sweden, and the UK, among which Estonia, Denmark, Finland, France, and Latvia developed design action plans. A list of national policies for design in EU member states is available at [21].

\section{References}

1. Freeman, C. The Economics of Industrial Innovation, 2nd ed.; Frances Pinter: London, UK, 1982.

2. Mutlu, B.; Alpay, E. Design Innovation: Historical and Theoretical Perspectives on Product Innovation by Design. In Proceedings of the 5th European Academy of Design Conference, Barcelona, Spain, 28-30 April 2003.

3. OECD. Technology and the Economy: The Key Relationships; OECD: Paris, France, 1992.

4. Li, C.; Coll-Serrano, V. Assessing the Role of Collaboration in the Process of Museum Innovation. J. Cult. Econ. 2019, 12, 590-606. [CrossRef] 
5. Bilton, C.; Leary, R. What Can Managers Do for Creativity? Brokering Creativity in the Creative Industries. Int. J. Cult. Policy 2002, 8, 49-64. [CrossRef]

6. Kimbell, L. Rethinking Design Thinking: Part I. Des. Cult. 2011, 3, 285-306. [CrossRef]

7. Brown, T. Change by Design: How Design Thinking Transforms Organizations and Inspires Innovation; Harper Collins: New York, NY, USA, 2009.

8. Bell, D.; Jayne, M. Assessing the Role of Design in Local and Regional Economies. Int. J. Cult. Policy 2003, 9, 265-284. [CrossRef]

9. Ettlie, J.E. Integrated Design and New Product Success. J. Oper. Manag. 1997, 15, 33-55. [CrossRef]

10. Perks, H.; Cooper, R.; Jones, C. Characterizing the Role of Design in New Product Development: An Empirically Derived Taxonomy*. J. Prod. Innov. Manag. 2005, 22, 111-127. [CrossRef]

11. Veryzer, R.W.; Borja de Mozota, B. The Impact of User-Oriented Design on New Product Development: An Examination of Fundamental Relationships*. J. Prod. Innov. Manag. 2005, 22, 128-143. [CrossRef]

12. Eklund, C. Innovation Capabilities, Design and Cutting Edge: Innovative Growth in the 21st Century; University of Vaasa: Vaasa, Finland, 2019.

13. Staszowski, E.; Brown, S.; Winter, B. Reflections on Designing for Social Innovation in the Public Sector: A Case Study in New York City. In Public and Collaborative: Exploring the Intensive of Design, Social Innovation and Public Policy; Manzini, E., Staszowski, E., Eds.; DESIS Network: New York, NY, USA, 2013; pp. $27-38$.

14. Chick, A. Design for Social Innovation: Emerging Principles and Approaches. Iridescent 2012, 2, 78-90. [CrossRef]

15. Brey, P. Design for the Value of Human Well-Being. In Handbook of Ethics, Values, and Technological Design: Sources, Theory, Values and Application Domains; Van den Hoven, J., Vermaas, P., van de Poel, I., Eds.; Springer: Berlin/Heidelberg, Germany, 2015; pp. 366-382. [CrossRef]

16. Larsson, A.; Larsson, T.; Leifer, L.; Van Der Loos, M.; Feland, J. Design for Wellbeing: Innovations for People. In Proceedings of the ICED 05, the 15th International Conference on Engineering Design, Melbourne, Australia, 15-18 August 2005; pp. 1-10.

17. Desmet, P.M.A.; Pohlmeyer, A.E. Positive Design: An Introduction to Design for Subjective Well-Being. Int. J. Des. 2013, 7, 5-19.

18. Hobday, M.; Boddington, A.; Grantham, A. Policies for Design and Policies for Innovation: Contrasting Perspectives and Remaining Challenges. Technovation 2012, 32, 272-281. [CrossRef]

19. Whicher, A. Design Policy Monitor 2014. 2014. Available online: https://www.academia.edu/10085387/ Design_Policy_Monitor_2014 (accessed on 17 January 2020).

20. Whicher, A.; Cawood, G.; Walters, A. Design Policy Monitor 2015. 2015. Available online: https://www.ico-d. org/database/files/library/SEE_DPM_2015_Jan.pdf (accessed on 17 January 2020).

21. Whicher, A.; Cawood, G.; Walters, A. Design Policy Monitor 2012. 2012. Available online: https://www.academia.edu/6710420/Design_Policy_Monitor_2012_Reviewing_Innovation_and_ Design_Policies_across_Europe (accessed on 17 January 2020).

22. DeEP. Design in Europe Policy. 2014. Available online: http://www.deepinitiative.eu/wp-content/uploads/ 2012/12/DEEP_FINAL-PUBLICATION.pdf (accessed on 17 January 2020).

23. Irvin, R.A.; Stansbury, J. Citizen Participation in Decision Making: Is It Worth the Effort? Public Adm. Rev. 2004, 64, 55-65. [CrossRef]

24. Sunstein, C.R.; Thaler, R.H. Libertarian Paternalism Is Not an Oxymoron. Univ. Chicago Law Rev. 2003, 70, 1159. [CrossRef]

25. Troussard, X.; van Bavel, R. How Can Behavioural Insights Be Used to Improve EU Policy? Intereconomics 2018, 53, 8-12. [CrossRef]

26. Love, T. Philosophy of Design: A Meta-Theoretical Structure for Design Theory. Des. Stud. 2000, 21, $293-313$. [CrossRef]

27. Alexander, C. Notes on the Synthesis of Form; Harvard University Press: Cambridge, MA, USA, 1964.

28. Zimring, C.M.; Graig, D.L. Defining Design between Domains: An Argument for Design Research. In Design Knowing and Learning: Cognition in Design Education; Eastman, C., McCracken, M., Newsletter, W., Eds.; Elservier Science: Amsterdam, The Netherlands, 2001; pp. 125-146.

29. Simon, H.A. The Sciences of the Artificial, 3rd ed.; MIT Press: Cambridge, MA, USA, 1996.

30. Hatchuel, A.; Weil, B. C-K Design Theory: An Advanced Formulation. Res. Eng. Des. 2009, 19, $181-192$. [CrossRef] 
31. Dorst, K. Design Problems and Design Paradoxes. Des. Issues 2006, 22, 4-17. [CrossRef]

32. Rowe, P.G. Design Thinking; MIT Press: Cambridge, MA, USA, 1987.

33. Visser, W. Simon: Design as a Problem-Solving Activity. In Collection, Parsons Paris School of Art and Design, 2010; Art + Design \& Psychology: Prague, Czech Republic, 2010; pp. 11-16.

34. Simon, H.A. The Structure of Ill Structured Problems. Artif. Intell. 1973, 4, 181-201. [CrossRef]

35. Rittel, H.; Webber, M. Planning Problems are Wicked Problems. In Developments in Design Methdology; Cross, N., Ed.; Wiley: Chichester, UK, 1984; pp. 135-144.

36. Visser, W. Design: One, but in Different Forms. Des. Stud. 2009, 30, 187-223. [CrossRef]

37. Baregheh, A.; Rowley, J.; Sambrook, S. Towards a Multidisciplinary Definition of Innovation. Manag. Decis. 2009, 47, 1323-1339. [CrossRef]

38. Mulgan, G. The Process of Social Innovation. Innovations 2006, 1, 145-162. [CrossRef]

39. Rothwell, R. Towards the Fifth-Generation Innovation Process. Int. Mark. Rev. 1994, 11, 7-31. [CrossRef]

40. Berkhout, A.J.; Hartmann, D.; Van Der Duin, P.; Ortt, R. Innovating the Innovation Process. Int. J. Technol. Manag. 2006, 34, 390-404. [CrossRef]

41. Stoneman, P. Soft Innovation: Economics, Product Aesthetics and the Creative Industies; Oxford University Press Inc.: New York, NY, USA, 2010.

42. Abbasi, M.; Cullen, J.; Li, C.; Molinari, F.; Morelli, N.; Rausell, P.; Simeone, L.; Stergioulas, L.; Tosoni, I.; Van Dam, K. A Triplet Under Focus: Innovation, Design and the City. In Innovation Capacity and the City. The Enabling Role of Design; Concilio, G., Tosoni, I., Eds.; Springer: Berlin/Heidelberg, Germany, 2019; pp. 15-41.

43. Cox, G. Cox Review of Creativity in Business: Building on the UK's Strengths; HM Treasury: London, UK, 2005.

44. Hillgren, P.-A.; Seravalli, A.; Emilson, A. Prototyping and Infrastructuring in Design for Social Innovation. CoDesign 2011, 7, 169-183. [CrossRef]

45. Karasti, H. Infrastructuring in Participatory Design. In Proceedings of the 13th Participatory Design Conference on Research Papers_PDC '14; ACM Press: New York, NY, USA, 2014; Volume 1, pp. 141-150. [CrossRef]

46. Morelli, N.; De Götzen, A.; Simeone, L. Design Capabilities for the Evolution of Value Creation. In Proceedings of the Academy for Design Innovation Management Conference, London, UK, 19-21 June 2019. [CrossRef]

47. Concilio, G.; De Götzen, A.; Molinari, F.; Morelli, N.; Mulder, I.; Simeone, L.; Tosoni, I.; Van Dam, K. Innovation and Design. In Innovation Capacity and the City. The Enabling Role of Design; Concilio, G., Tosoni, I., Eds.; PoliMI SpringerBriefs: Cham, Switzerland, 2019.

48. Concilio, G.; Cullen, J.; Tosoni, I. Design Enabled Innovation in Urban Environments. In Innovation Capacity and the City. The Enabling Role of Design; Concilio, G., Tosoni, I., Eds.; PoliMI SpringerBriefs: Cham, Switzerland, 2019.

49. Design Council. Understanding Design-Intensive Innovation: A Literature Review; Design Council: London, UK, 2018.

50. Gemser, G.; Leenders, M.A.A.M. How Integrating Industrial Design in the Product Development Process Impacts on Company Performance. J. Prod. Innov. Manag. 2001, 18, 28-38. [CrossRef]

51. Cantamessa, M.; Cascini, G.; Montagna, F. Design for Innovation. In Proceedings of the International Design Conference, DESIGN, Dubrovnik, Croatia, 21-24 May 2012.

52. Hodges, N.J.; Link, A.N. Innovation by Design. Small Bus. Econ. 2019, 52, 395-403. [CrossRef]

53. Bucolo, S.; Matthews, J.H. Design Led Innovation: Exploring the Synthesis of Needs, Technologies and Business Models. In Proceedings of Participatory Interaction Conference; University of Southern Denmark: Odense, Denmark, 2011.

54. Townson, P.; Matthews, J.; Wrigley, C. Outcomes from Applying Design-Led Innovation in an Australian Manufacturing Firm. Technol. Innov. Manag. Rev. 2016, 6, 49-58. [CrossRef]

55. Verganti, R. Design, Meanings, and Radical Innovation: A Metamodel and a Research Agenda. J. Prod. Innov. Manag. 2008, 25, 436-456. [CrossRef]

56. Verganti, R. Design Driven Innovation: Changing the Rules of Competition by Radically Innovating What Things Mean; Harvard Business Press: Boston, MA, USA, 2009.

57. Yamamoto, M.; Lambert, D.R. The Impact of Product Aesthetics on the Evaluation of Industrial Products. J. Prod. Innov. Manag. 1994, 11, 309-324. [CrossRef]

58. Norman, D.A.; Verganti, R. Incremental and Radical Innovation: Design Research vs. Technology and Meaning Change. Des. Issues 2014, 30, 78-96. [CrossRef] 
59. Battistella, C.; Biotto, G.; De Toni, A.F. From Design Driven Innovation to Meaning Strategy. Manag. Decis. 2012, 50, 718-743. [CrossRef]

60. Liedtka, J. Why Design Thinking Works. Harv. Bus. Rev. 2018, 96, 72-79.

61. Concilio, G.; Tosoni, I. Introduction. In Innovation Capacity and the City. The Enabling Role of Design; Concilio, G., Tosoni, I., Eds.; Springer: Berlin/Heidelberg, Germany, 2019; pp. 1-14.

62. Geels, F.W.; Schot, J. Typology of Sociotechnical Transition Pathways. Res. Policy 2007, 36, 399-417. [CrossRef]

63. Boland, R.J.; Collopy, F.; Lyytinen, K.; Yoo, Y. Managing as Designing: Lessons for Organization Leaders from the Design Practice of Frank O. Gehry. Des. Issues 2008, 24, 10-25. [CrossRef]

64. Manzini, E. Design, When Everybody Designs; MIT Press: Cambridge, MA, USA, 2015.

65. Costa, N.; Patrício, L.; Morelli, N.; Magee, C.L. Bringing Service Design to Manufacturing Companies: Integrating PSS and Service Design Approaches. Des. Stud. 2018, 55, 112-145. [CrossRef]

66. Roos, G. Design-Based Innovation for Manufacturing Firm Success in High-Cost Operating Environments. She Ji J. Des. Econ. Innov. 2016, 2, 5-28. [CrossRef]

67. Na, J.H.; Choi, Y.; Harrison, D. The Design Innovation Spectrum: An Overview of Design Influences on Innovation for Manufacturing Companies. Int. J. Des. 2017, 11, 13-24.

68. Design Council. Design Methods for Developing Services; Design Council: London, UK, 2007.

69. Zomerdijk, L.G.; Voss, C.A. Service Design for Experience-Centric Services. J. Serv. Res. 2010, 13, 67-82. [CrossRef]

70. Valentine, L.; Kroll, T.; Bruce, F.; Lim, C.; Mountain, R. Design Thinking for Social Innovation in Health Care. Des. J. 2017, 20, 755-774. [CrossRef]

71. Van der Westhuizen, D.; Conrad, N.; Douglas, T.S.; Mutsvangwa, T. Engaging Communities on Health Innovation: Experiences in Implementing Design Thinking. Int. Q. Community Health Educ. 2020. [CrossRef]

72. Hendricks, S.; Conrad, N.; Douglas, T.S.; Mutsvangwa, T. A Modified Stakeholder Participation Assessment Framework for Design Thinking in Health Innovation. Healthcare 2018, 6, 191-196. [CrossRef]

73. SEE Platform. Design for Public Good. Ann. Rev. Policy Des. 2013, 1, 1-50.

74. Hermus, M.; van Buuren, A.; Bekkers, V. Applying Design in Public Administration: A Literature Review to Explore the State of the Art. Policy Polit. 2020, 48, 21-48. [CrossRef]

75. Raulik-Murphy, G.; Cawood, G.; Lewis, A. Design Policy: An Introduction to What Matters. Des. Manag. Rev. 2010, 21, 52-59. [CrossRef]

76. Mortati, M.; Maffei, S. Researching Design Policy Ecosystems in Europe. She Ji J. Des. Econ. Innov. 2018, 4, 209-228. [CrossRef]

77. The Danish Enterprise and Construction Authority. The Vision of the Danish Design 2020 Committee; The Danish Enterprise and Construction Authority: Copenhagen, Denmark, 2011.

78. European Commission. Design as a Driver of User-Centred Innovation; European Commission: Brussels, Belgium, 2009.

79. European Commission. Europe 2020 Flagship Initiative Innovation Union; European Commission: Brussels, Belgium, 2010.

80. Schuster, M. Mapping State Cultural Policy. In Mapping State Cultural Policy: The State of Washington; Schuster, M., Ed.; The University of Chicago: Chicago, IL, USA, 2003; pp. 1-20.

81. Paulina, R.; Modrzewski, A.F. Project Design Silesia and Its Role of Development in Polish Post-Industrial's Region. Glob. J. Interdiscip. Soc. Sci. 2014, 3, 21-26.

82. Rausell Köster, P. Políticas y Sectores Culturales En La Comunidad Valenciana; Tirant lo Blanch: Valencia, Spain, 1999.

83. Glaister, K.W.; Falshaw, J.R. Strategic Planning: Still Going Strong? Long Range Plann. 1999, 32, $107-116$. [CrossRef]

84. Proctor, R.A. Structured and Creative Approaches to Strategy Formulation. Manag. Res. News 1992, 15, 13-18. [CrossRef]

85. Helms, M.M.; Nixon, J. Exploring SWOT Analysis-Where Are We Now? J. Strateg. Manag. 2010, 3, $215-251$. [CrossRef]

86. Yin, R.K. Case Study Research: Design and Methods, 4th ed.; Sage Publications: Los Angeles, CA, USA, 2009.

87. Lundvall, B.-Å. National Innovation Systems-Analytical Concept and Development Tool. Ind. Innov. 2007, 14, 95-119. [CrossRef] 
88. Ranga, M.; Etzkowitz, H. Triple Helix Systems: An Analytical Framework for Innovation Policy and Practice in the Knowledge Society. Ind. High. Educ. 2013, 27, 237-262. [CrossRef]

89. Etzkowitz, H. The Triple Helix. University-Industry-Government Innovation in Action; Routledge: New York, NY, USA, 2008. [CrossRef]

90. Landoni, P.; Dell'Era, C.; Ferraloro, G.; Peradotto, M.; Karlsson, H.; Verganti, R. Design Contribution to the Competitive Performance of SMEs: The Role of Design Innovation Capabilities. Creat. Innov. Manag. 2016, 25, 484-499. [CrossRef]

(C) 2020 by the authors. Licensee MDPI, Basel, Switzerland. This article is an open access article distributed under the terms and conditions of the Creative Commons Attribution (CC BY) license (http://creativecommons.org/licenses/by/4.0/). 